\title{
ANALISIS KEMAMPUAN PENALARAN LOGIS MAHASISWA PROGRAM STUDI PENDIDIKAN MATEMATIKA PADA MATA KULIAH PENGANTAR DASAR MATEMATIKA
}

\begin{abstract}
$\operatorname{Aisyah}^{1}$
Abstrack : Logical reasoning is reasoning that in accordance with the rules of logic. The purpose of this research is the goal of this research is to describe the logical reasoning abilities of students semester II Prodi mathematics education FKIP UNBARI JAMBI academic year 2015/2016 Introductory courses on the foundations of mathematics. This research includes qualitative research types that use descriptive qualitative research methodology. While the subject of the intended research i.e. students semester II Prodi mathematics

education FKIP UNBARI. The technique of data collection conducted in research this is a test, documentation, and interviews. Further data analysis techniques that will be performed include 1) data reduction (reduction of data); 2)datadisplay(exposure data/categorization); and

3) conclusion drawing/verification (withdrawal of the conclusions).
\end{abstract}

Keyword : Logical Reasoning Ability, Analysis, Introduction To The Foundations Of Mathematics

\section{PENDAHULUAN}

Pendidikan nasional yang tercantum dalam UU No. 20 Tahun 2003 menyebutkan bahwa "pendidikan nasional bertujuan bertujuan untuk berkembangnya potensi peserta didik agar menjadi manusia yang beriman dan bertakwa kepada Tuhan Yang Maha Esa, berakhlak mulia, sehat, berilmu, cakap, kreatif, mandiri, dan menjadi warga negara yang demokratis, serta bertanggung jawab (Sukardjo dan Ukim, 2010:14). Dapat diartikan tujuan pendidikan memberikan penyadaran terhadap apa yang diketahui, kemudian pengetahuan tersebut harus di realisasikan sendiri dan selanjutnya mengadakan penelitian serta mengetahui hubungan kausal, yaitu alasan dan alur pikirnya.

Aristoteles yang merupakan filsuf kenamaan mengatakan bahwa tujuan pendidikan merupakan penyadaran terhadap self realization, yaitu kekuatan efektif (virtue) kekuatan untuk menghasilkan (efficacy) dan potensi untuk mencapai kebahagiaan hidup melalui kebiasaan dan kemampuan berpikir rasional (Sukardjo dan Ukim, 2010:14).

Dalam aspek berpikir, kegiatan ini merupakan penalaran yang reflkektif, kritis dan kreatif, yang berorientasi pada suatu proses intelektual yang melibatkan pembentukan konsep (conceptualizing), aplikasi, analisis, menilai informasi yang terkumpul (sintesis) atau dihasilkan melalui pengamatan, pengalaman, refleksi, atau komunikasi sebagai landasan kepada satu keyakinan (kepercayaan) dan tindakan. Beragam kemampuan ini membutuhkan pemikiran yang sistematis, logis, dan kritis yang dapat dikembangkan melalui pembelajaran matematika.

\footnotetext{
${ }^{1}$ Dosen Program Studi Pendidikan Matematika Universitas Batanghari
} 
Dapat diambil suatu pemahaman bahwa matematika menjadi poin penting untuk membentuk pola pikir yang sistematus dan logis. Seiring dengan hal ini Rostina (2013: 2) menyebutkan bahwa matematika adalah bekal bagi peserta didik untuk berpikir logis, analitis, sistematis, kristis, dan kreatif.

Mengingat banyaknya aspek berpikir tersebut, peneliti hanya fokus pada aspek berpikir logis. Kata logika sering didefinisikan sebagai kecakapan menalar, berpikir dengan tepat (Jacobus 2014:3). Penalaran adalah kegiatan berpikir yang mempunyai karakteristik tertentu dalam menemukan kebenaran, dimana setiap jenis penalaran itu memiliki kriteria kebenarannya masing-masing.Kegiatan berpikir semacam ini disebut "berpikir logis", yaitu menarik kesimpulan dari adanya suatu hubungan kausal itulah yang disebut sebagai penalaran(Jacobus, 2014:51).

Dalam prosesnya, bernalar secara logis merupakan akrivitas menggali informasi dan menerjemahkannya dalam upaya menarik suatu kesimpulan sebagai solusi. Seiring dengan ini, Galotti (Jacob, 2007:2) menjelaskan bahwa bernalar logis merupakan upaya mentransformasikan informasi yang diberikan untuk memperoleh konklusi.Dengan kata lain penalaran logis adalah penalaran yang sesuai dengan aturan-aturan logika.

Berpikir dan bernalar secara logis sangat diperlukan dalam setiap aspek kehidupan sehari-hari, karena penalaran logis merupakan pendukung keberhasilan suatu tindakan, terutama dalam mengambil keputusan. Hal ini tentunya sangat dibutuhkan oleh setiap orang dalam menjalankan kehidupannya. Oleh karena itu sudah selayaknya kajian tentang kemampuan penalaran logis ini mendapat perhatian lebih pada setiapa jenjang pendidikan terutama di Perguruan Tinggi.Betapa tidak, di Perguruan Tinggipeserta didik yang digembleng merupakan manusia dewasa yang sudah selayaknya memiliki kemampuan penalaran yang logis. Mengingat pola pembelajarannya yang menuntut peserta didiknya (dalam hal ini adalah mahasiswa) berpikir dan bertindak secara mandiri.

Uraian diatas menjadi dasar bagi peneliti untuk melakukan penelitian di dengan judul Analisis Kemampuan Penalaran Logis Mahasiswa Program Studi Pendidikan Matematika pada Mata Kuliah Pengantar Dasar Matematika. Berdasarkan uraian latar belakang masalah di atas maka peneliti merumuskan masalahnya yaitu, bagaimanakah kemampuan penalaran logis mahasiswa semester II Prodi Pendidikan Matematika FKIP UNBARI JAMBI tahun akademik 2015/2016 pada mata kuliah Pengantar Dasar Matematika? Sesuai dengan rumusan masalah, maka tujuan penelitian ini adalah mendeskripsikan kemampuan penalaran logis mahasiswa semester II Prodi Pendidikan Matematika FKIP UNBARI JAMBI tahun akademik 2015/2016 pada mata kuliah Pengantar Dasar Matematika. 


\section{Landasan Teori}

Penalaran terjemahan dari bahasa inggris reasoning, menurut kamus The Rendom House Dictionary berarti kegiatan atau proses menalar yang dilakukan seseorang adalah kekuatan mental yang di berkaitan dengan pembentukan kesimpulan dan penilaian. Shuten dan Pierce mengemukakan bahwa penalaran sebagai proses pencapaian kesimpulan logis berdasarkan fakta dan sumber yang relevan. Penalaran menurut Fadjar Shadiq adalah suatu proses atau suatu aktivitas berpikir untuk menarik suatu kesimpulan atau proses berpikir dalam rangkan membuat suatu pernyataan baru yang berdasarkan pada beberapa pernyataan yang kebenarannya telah dibuktikan atau diasumsikan sebelumnya (Mia, 2011:18).

Logika berasal dari bahasa Yunani "logos", artinya sabda, pikiran, ilmu. Secara etimologis, logika adalah ilmu tentang pikiran atau ilmu menalar. Kata logika atau logis dipakai dalam arti yang sama dengan masuk akal atau dapat di mengerti (Jacobus, 2014:2). Logis dapat diartikan sebagai sesuatu yang sesuai dengan logika, benar menurut penalaran dan masuk akal.Logis dalam matematika sering dikaitkan dengan penggunaan aturan logika. Saragih mengungkapkan bahwa berpikir logis mempunyai perbedaan dengan menghafal. Menghafal hanya mengacu pada pencapaian kemampuan ingatan belaka, sedangkan berpikir logis lebih mengacu pada pemahaman pengertian (dapat mengerti), kemampuan aplikasi, kemampuan analisis, kemampuan sintesis, bahkan kemampuan evaluasi untuk membentuk kecakapan (Maya dan Aziz, 2012:574).

Indikator kemampuan penalaran logisdalam penelitian ini merujuk kepada teori Hartono (2013: 202) sepertidalam tabel berikut :

Tabel 1

Indikator Penalaran Logis

\begin{tabular}{|c|l|l|}
\hline No. & \multicolumn{1}{|c|}{$\begin{array}{c}\text { Indikator Penalaran } \\
\text { Logis }\end{array}$} & \multicolumn{1}{|c|}{ Deskriptor Indikator Penalaran Logis } \\
\hline 1. & Mengumpulkan fakta & $\begin{array}{l}\text { 1. Menuliskan fakta yang diketahui dari } \\
\text { permasalahan secara lengkap dan terurut. } \\
\text { 2. Menganalisis setiap keadaan dengan } \\
\text { merangkai kata-kata sendiri. }\end{array}$ \\
\hline 2. & $\begin{array}{l}\text { Membagun dan } \\
\text { menetapkan asumsi }\end{array}$ & $\begin{array}{l}\text { 1. Memiliki dua cara dalam menyelesaikan } \\
\text { masalah. } \\
\text { 2. Menuliskan langkah-langkah penyelesaian } \\
\text { masalah secara lengkap tetapi terkadang } \\
\text { hanya menuliskan sebagian atau tidak } \\
\text { menuliskannya. }\end{array}$ \\
\hline 3. & $\begin{array}{l}\text { Menilai atau menguji } \\
\text { asumsi }\end{array}$ & $\begin{array}{l}\text { 1. Membuat argumen dengan beberapa } \\
\text { asumsi tertentu. } \\
\text { 2. Tidak menyelesaikan permasalahan sesuai } \\
\text { dengan yang direncanakan. }\end{array}$ \\
\hline 4. & Menetapkan generalisasi & $\begin{array}{l}\text { Mampu membuat satu pernyataan sebagai } \\
\text { simpualan dari uraian pengujian asumsi }\end{array}$ \\
\hline 5. & $\begin{array}{l}\text { Membangun argumentasi } \\
\text { yang mendukung }\end{array}$ & $\begin{array}{l}\text { Mempunyai asumsi atau cara lain untuk } \\
\text { memperoleh hasil yang sama. }\end{array}$ \\
\hline 6. & Memeriksa atau menguji & \begin{tabular}{l} 
Mengeksekusi cara lain untuk memperoleh hasil \\
\hline
\end{tabular} \\
\hline
\end{tabular}




\begin{tabular}{|c|l|l|}
\hline & kebenaran argumen & yang sama. \\
\hline 7. & Menetapkan kesimpulan & 1. Menarik kesimpulan berdasarkan pekerjaan \\
& & tertulisnya. \\
& & 2. Terkadang mempunyai argumen yang \\
mendukung jawabannya dalam menarik \\
kesimpulan.
\end{tabular}

(Sumber : modifikasi dari teori Hartono)

Soal tes merupakan salah satu alat yang digunakan untuk melakukan penilaian hasil belajar. Dalam hal ini adalah soal tes pada mata kuliah Pengantar Dasar Matematika. Soal yang digunakan berbentuk uraian. Digunakannnya soal berbetuk uraian bertujuan untukmenuntut mahasiswa memberikan responatau menguraikan langkah-langkah dalam memperoleh jawaban atas soal tersebut. Soal uraian dibagi menjadi soal uraian terbatas (objektif) dan uraian bebas (non objektif) dalam hal variasi cara memperoleh dan macam jawaban. Pada matematika dipakai uraian terbatas (Hamzah, 2014:42). Tes uraian terbatas digunakan untuk memperbanyak sampel materi, untuk mempermudah pemeriksaan hasil ujian. Tes ini mempunyai jawaban yang sudah terstruktur berdasarkan kunci jawabannya sehingga materi tes akan lebih banyak dibanding tes terbuka. Tes uraian terbuka mempunyai sampel materi sedikit yang dapat diambil (Hamzah, 2014:141). Berdasarkan penjelasan tersebut soal-soal penalaran logis yang digunakan dalam menyelesaikan tes pada mata kuliah Pengantar Dasar Matematika termasuk soal terbatas.

\section{METODE}

Penelitian ini termasuk jenis penelitian kualitatif yang menggunakan metodologi penelitian kualitatif deskriptif. Penelitian deskriptif merupakan metode yang berusaha menggambarkan dan menginterprestasi objek sesuai dengan apa adanya. Penelitian ini juga sering disebut noneksperimen, karena pada penelitian ini tidak melakukan kontrol dan manipulasi variabel penelitian.Penelitian deskriptif pada umumnya dilakukan dengan tujuan utama, yaitu menggambarkan secara sistematis fakta dan karakteristik objek atau subjek yang di teliti secara tepat (Sukardi, 2012: 157).Penelitian deskriptif menghasilkan data berupa kata-kata tertulis atau lisan dan tidak berupa angka-angka.

Subjek penelitian ini adalah mahasiswa semester II pada tahun akademik 2015/2016 yang mengikuti perkuliahan Pengantar Dasar Matematika.

Menurut Lofland sumber data utama dalam penelitian kualitatif ialah katakata dan tindakan, selebihnya adalah data tambahan seperti dokumen dan lain-lain (Moleong, 2010: 157). Arikunto mengatakan yang dimaksud sumber data dalam penelitian ini adalah subjek dari mana data diperoleh (2010 : 172).Sumber data diambil menggunakan teknik purposive sampling.Purposivesampling adalah teknik pengambilan subjek sumber data dengan pertimbangan tertentu (Sugiono, 2014:300). Dalam teknik purposive sampling anggota sampel dapat dipilih berdasarkan tujuan tertentu dan dapat menentukan subjek atau objek sesuai tujuan 
(Satori dan Komariah, 2011: 47). Data dalam penelitian ini berupa : 1) Hasil tes kemampuan penalaran logis mahasiswa yang diperoleh melalui pemberian soal, 2) Hasil wawancara mengenaikemampuan mahasiswa berdasarkan pada indikator penalaran logis.

Instrumen penelitian adalah alat atau fasilitas yang digunakan oleh peneliti dalam mengumpulkan data agar pekerjaannya lebih mudah dan hasilnya lebih baik, dalam arti lebih cermat, lengkap dan sistematis sehingga lebih mudah diolah (Arikunto, 2010: 209). Menurut Sugiyono (2010: 222) yang menjadi instrument atau alat penelitian dalam penelitian kualitatif adalah peneliti itu sendiri. Selanjutnya Moleong (2007: 167) berpendapat bahwa dalam penelitian kualitatif kedudukan peneliti cukup rumit yaitu sebagai instrument penelitian. Karena penelitian ini bersifat kualitatif, maka yang menjadi instrument kunci (pengumpul data) adalah peneliti itu sendiri yang dipandu dengan lembar tes pertanyaan mta kuliah Pengantar Dasar Matematika. Sebagai instrument utama, peneliti berperan sebagai perencana, pelaksana pengumpul data, penganalisis, penafsir data, dan akhirnya menjadi pelapor hasil penelitiannya.

Tes kemampuan penalaran logis menggunakan soal yang telah disusun berdasarkan sebaran materi kuliah yang disampaikan selama satu semester. Tes ini merupakan paket soal yang trdiri dari dua paket soal yaitu paket soal I dan paket soal II. Dimana paket soal II analog dengan paket soal satu. Hal ini dimaksudkan agar dalam memperoleh informasi terkait kemampuan mahasiswa lebih sahih dengan melakukan triangulasi dilain waktu. Sebelum diberikan pada subjek penelitian, paket soal ini terlebih dahulu dilakukan validasi kepada ahli yang bertujuan untuk memberikan analisis terhadap paket soal yang deisediakan. Dengan adanya analisis soal tersebut, dapat diperoleh informasi tentang kejelekan sebuah soal dan petunjuk untuk mengadakan perbaikan sehingga dianggap layak untuk digunakan.

Pedoman wawancara dimaksudkan untuk mengarahkan penelitian dalam mengungkap kemampuan penalaran logis mahasiswa dan bagian kemampuan penalaran logis mana yang paling dominan dimiliki oleh mahasiswa. Pedoman wawancara hanya membimbing penelitian agar materi wawancara tetap focus padahal-hal yang ingin diungkapkan. Sedangkan dalam pelaksanaannya peneliti dapat mengembangkan sesuai dengan kondisi yang sedang dialami saat itu, tetapi masih tetap mengacu pada pedoman wawancara. Data hasil wawancara berupa transkrip wawancara yang berisi jawaban dari pertanyaan peneliti setelah diajukan kepada mahasiswa terkait penyelesaian soal yang diberikan. Berdasarkan transkrip tersebut, data tentang kemampuan penalaran logis mahasiswa dapat dideskripsikan.

Adapun prosedur pengumpulan data dalam penelitian ini dilakukan sesuai dengan langkah-langkah sebagai berikut:

1. Peneliti memberikan soal tes kemampuan penalaran logis paket I kepada seluruh mahasiswa. Peneliti member kesempatan kepada mahasiswa untuk memahami dan menjawab soal selama 100 menit.

2. Peneliti mencatat kegiatan subjek ketika meninjau kembali hasil yang sudah diperoleh, dan melakukan wawancara untuk mengungkap bagaimana 
kemampuan penalaran logis yang dimiliki mahasiswa dan indicator manakah yang paling dominan.

3. Pada hari yang berbeda peneliti memberikan tes kemampuan penalaran logis kedua yang mirip dengan tes I (disebut sebagai paket II) kepada subjek.

4. Peneliti kembali mencatat kegiatan subjek ketika meninjau kembali hasil yang sudah diperoleh, dan melakukan wawancara untuk mengungkap bagaimana kemampuan penalaran logis yang dimiliki mahasiswa dan indikator manakah yangp aling dominan.

5. Setelah data terkumpul, selanjutnya dilakukan pengecekan keabsahan data dengan triangulasi waktu, yaitu menggunakan pengulangan wawancara, yaitu mencari kesesuaian data yang bersumber dari dua masalah yang setara. Peneliti melakukan validasi terhadap data tes pertama dan data tes kedua. Apabila data tes pertama dan kedua menunjukkan kesamaan, maka kedua data tersebut dikatakan valid dan reliabel, sehingga dapat dilakukan analisis untuk memperoleh identifikasi kemampuan penalaran logis mahasiswa. Sebaliknya apabila kedua data itu tidak valid maka diberikan lagi tes kemampuan penalaran logis berikutnya. Proses seperti ini berlangsung terus sampai ditemukan data yang valid.

Uji kredibilitas data atau kepercayaan terhadap data hasil penelitian kualitatif dapat dilakukan dengan perpanjangan pengamatan, peningkatan ketemukan, tringulasi, menggunakan diskusi dengan teman sejawat, analisis kasus negatif dan member Check (Sugiono, 2014:368). Tringulasi dalam pengujian kredibilitas ini diartikan sebagai pengecekan data dari berbagai sumber, dengan berbagai cara, dan berbagai waktu. Pada penelitian ini uji kredibilitas data atau kepercayaan terhadap data hasil penelitian dilakukan dengan tringulasi waktu.

Untuk mempertanggungjawabkan kredibilitas dalam penelitian ini, peneliti melakukan langkah-langkah sebagai berikut:

1. Melakuan triangulasi waktu. Tringulasi waktu adalah teknik pengecekan keabsahan data dengan menggunakan metode yang sama pada subjek tetapi pada waktu yang berbeda. Triangulasi Waktu yang dilakukan peneliti yaitu seminggu setelah pemberian tes pertama (soal paket I) dengan melakukan pengulangan wawancara dengan tes yang setara. Triangulasi waktu dilakukan dengan tujuan untuk mencari kesesuaian data yang bersumber dari dua masalah yang setara pada waktu yang berbeda. Hasil wawancara dan hasil tes tertulis dikaji berdasarkan indicator kemampuan penalaran logis. Penelitian yang pengecekan derajat kebenaran datanya dengan menggunakan triangulasi waktu akan lebih valid hasilnya karena peneliti dapat membandingkan data yang diperoleh dari subjek yang sama dengan waktu yang berbeda sehingga hasilnya akan lebih meyakinkan. Dengan cara demikian diharapkan keseluruhan data saling menguatkan dan memberikan pemahaman yang lebih mendalam mengenai kemampuan penalaran logis.

2. Membuat catatan setiap tahapan penelitian dan dokumentasi yang lengkap. Secara berkala peneliti melakukan refleksi mengenai pemikiran-pemikiran yang muncul dan tindakan-tindakan yang telah dilakukan. 
3. Melakukan pentranskripan segera setelah melakukan pengambilan data. Hal ini dilakukan agar unsur-unsur subyektifitas peneliti tidak ikut mengintervensi data penelitian.

4. Melakukan pengecekan berulangkali terhadap lembar jawaban dan transkrip wawancara agar diperoleh hasil yang sahih.

Analisis data dalam penelitian ini dilakukan pada saat pengumpulan data berlangsung, dan setelah selesai pengumpulan data dalam periode tertentu. Pada saat wawancara, peneliti sudah melakukan analisis terhadap jawaban yang di wawancarai. Bila jawaban yang di wawancarai setelah di analisis terasa belum memuaskan, maka peneliti akan melanjutkan pertanyaan lagi, sampai tahap tertentu, di peroleh data yang dianggap kredibel. Miles dan Huberman mengemukakan bahwa aktivitas dalam analisis data kualitatif dilakukan secara interaktif dan berlangsung secara terus menerus sampai tuntas, sehingga datanya sudah jenuh. Aktivitas analisis data (Sugiono, 2014:337) yaitu (1) reduksi data, (2) penyajian data, (3) penarikan kesimpulan / verifikasi.

1. Reduksi data adalah merangkum, memilih hal-hal yang pokok, menfokuskan pada hal-hal yang penting, dicari tema dan polanya dan membuang yang tidak perlu. Reduksi data yang dilakukan dalam penelitian ini, yaitu kegiatan yang mengacu pada proses pemilihan dan pengidentifikasian data yang memiliki makna jika dikaitkan dengan pertanyaan penelitian, dan selanjutnya membuat pengelompokkan pada setiap satuan sehingga diketahui berasal dari mana sumbernya.

2. Penyajian data meliputi pengklasifikasian dan identifikasi data, yaitu menuliskan data yang terorganisasi dan terkategori sehingga memungkinkan untuk menarik kesimpulan dari data tersebut. Penyajian data ini dapat dilakukan dalam bentuk tabel, grafik, dan sejenisnya. Melalui penyajian data tersebut maka data terorganisasikan, tersusun dalam pola hubungan, sehingga akan semakin mudah dipahami. Terkategori yang dimaksudkan untuk : (1) mengelompokkan bagian-bagian data yang berkaitan, (2) merumuskan aturan yang menguraikan kawasan kategori dan akhirnya dapat digunakan untuk menetapkan inklusi kategori dan juga sebagai dasar pemeriksaan keabsahan data, dan (3) menjaga agar setiap kategori yang telah disusun dengan yang lainnya mengikuti prinsip langkah yang telah ditentukan, kemudian melakukan analisis data.

3. Penarikan kesimpulan / verifikasi, adalah penarikan kesimpulan didasarkan pada hasil analisis data terhadap data yang telah terkumpul, baik hasil pekerjaan tertulis maupun yang diperoleh dari hasil wawancara. Penarikan kesimpulan didasarkan pada indikator kemampuan penalaran logis dalam menyelesaikan soal-soal pada mata kuliah Pengantar Dasar Matematika.

\section{HASIL}

Data hasil penelitian ini meliputi data kuantitatif dan kualitatif. Data kuantitatif adalaha skor hasil tes dan data kualitatif adalah hasil analisis tes I dan II terhadap 30 orang mahasiswa. Data tersebut disajikan pada tabel berikut.

Tabel 2 menjelaskan bahwa indikator penalaran logis paling tinggi adalah mengumpulkan fakta. Hasil pengamatan peneliti terhadap kinerja mahasiswa 
diketahui sebagian besar mahasiswa dapat menuliskan informasi yang diketahui dari soal. Namun tidak semua mahasiswa yang telah mampu mengumpulkan fakta, dapat mebangun dan menetapkan asumsi. Begitu juga dalam menguji asumsi dan mengeneralisasikan hasil pengujian asumsi masih banyak mahasiswa yang belum mampu melakukannya dengan benar. Bahkan ada mahasiswa yang tidak membuat generalisasi dari pengujian asumsinya. Walaupun begitu, sebagian besar mahasiswa membuat argumen lain sebagai pendukung, selanjutnya menunjukkan pengujian terhadap argumen tersebut. Namun hanya sekitar separuhnya yang membuat kesimpulan dengar benar, terlihat dari hasil tes I hanya $50 \%$ dan pada tes II $56 \%$.

Tabel 2

Persentase Hasil Tes

\begin{tabular}{|c|l|c|c|}
\hline \multirow{2}{*}{ No. } & \multicolumn{2}{|c|}{ Indikator Penalaran Logis } & \multicolumn{2}{|c|}{ Persentase Jawaban } \\
\cline { 3 - 4 } & & Tes I & Tes II \\
\hline 1. & Mengumpulkan fakta & $86,67 \%$ & $90 \%$ \\
\hline 2. & Membangun dan menetapkan asumsi & $83,33 \%$ & $86,67 \%$ \\
\hline 3. & Menilai atau menguji asumsi & $76 \%$ & $76,67 \%$ \\
\hline 4. & Menetapkan generalisasi & $63,33 \%$ & $66,67 \%$ \\
\hline 5. & $\begin{array}{l}\text { Membangun argumentasi yang } \\
\text { mendukung }\end{array}$ & $70 \%$ & $73,33 \%$ \\
\hline 6. & $\begin{array}{l}\text { Memeriksa atau menguji kebenaran } \\
\text { argumen }\end{array}$ & $60 \%$ & $60 \%$ \\
\hline 7. & Menetapkan kesimpulan & $50 \%$ & $56,67 \%$ \\
\hline
\end{tabular}

Sumber : Data Olahan

Informasi yang diperoleh melalui wawancara, untuk indikator kemampuan penalaran logis yang pertama yaitu mengumpulkan fakta diketahui bahwa sebagian besar mahasiswa mengetahui fakta dari soal namun masih ada yang menuliskannya tidak lengkap dikarenakan tidak menganalisis setiap kata selanjutnya juga tidak mendeskripsikan sesuai dengan apa yang dipikirkannya menggunakan kalimat sendiri. Dengan kata lain, masih ada 4 orang mahasiswa pada tes I dan 3 orang mahasiswa pada tes II yang tidak mengumpulkan fakta secara cermat dan benar.

Hasil wawancara untuk indikator kemampuan penalaran logis yang kedua membangun dan menetapkan asumsi, diketahui sebagian besar mahasiswa dapat melakukannya dengan baik. Pada tahap ini rata-rata mahasiswa telah memiliki pendapat dan mampu mendeskripsikan langkah-langkah penyelesaian soal. Meskipun masih ada mahasiswa yang tidak melakukannya ataupun salah dalam mendeskripsikan penyelesaian soal pada tes I terdapat 5 orang mahasiswa dan tes II 4 orang mahasiswa.

Indikator penalaran logis yang ketiga menilai atau menguji asumsi, sekitar tiga perempat mahasiswa mampu melakukannya dengan benar yaitu mampu menyelesaikan soal sesuai dengan langkah-langkah penyelesaian yang benar. Namun terdapat 7 orang yang masih salah dalam menyelesaikan soal sesuai dengan langkah-langkah penyelesaiannya. Hasil wawancara menunjukkan bahwa mahasiswa tersebut kesulitan menyelesaikan soal sesuai dengan langkah-langkah 
yang benar dikarenakan tidak mengerti secara keseluruhan materi kuliah yang terkait dengan soal.

Pada indikator penalaran logis yan keempat menetapkan generalisasi, lebih dari separuh mahasiswa menuliskan generalisasi. Tetapi ada 12 orang pada tes I dan 11 orang pada tes II yang belum mampu melakukannya dengan baik.Melalui aktivitas wawancara diketahui bahwa mahasiswa kesulitan dalam menetapkan suatu pernyataan sebagai simpulan akhir dari pengujian asumsi.

Indikator kelima membangun argumen yang mendukung, sebagian besar mahasiswa mampu menuliskan asumsi yang mendukung dalam memperoleh kesimpulan. Dari hasil wawancara diketahui bahwa sebagian mahasiswa memang menuliskan asumsi berdasarkan teorema lain yang terkait untuk menyelesaikan soal, namun sebagiannya lagi menuliskan asumsi berdasarkan nalar saja tetapi logis. Sehingga $70 \%$ mahasiswa pada tes I dan 73,33\% pada tes II memuliki asumsi dan cara lain untuk memperoleh jawaban yang sama dan benar.

Pada indikator yang keenam memeriksa atau menguji kebenaran, 60\% mahasiswa mampu melakukannya dengan baik pada tes I maupun tes II. Berdasarkan hasil wawancara yang mendalam dengan mahasiswa diketahui bahwa ada 12 orang mahasiswa yang tidak dapat melakukan tahap ini dengan baik karena tidak melakukan pemeriksaan ulang jawaban yang dituliskan sebab waktu ujian telah selesai. Selain itu juga ada yang memang tidak mengetahui cara lain untukmenguji kebenaran jawaban yamg dituliskan.

Indikator terakhir dari kemampuan penalaran logis adalah menetapkan kesimpulan, yang hanya $50 \%$ pada tes I dan 56,67\% pada tes II mahasiswa mampu melakukanmya dengan benar. Dari hasil wawancara diketahui bahwa mahasiswa tidak dapatmenarik kesimpulan dengan benar karena tidak yakin dengankesimpulan yang dibuat disebabkan oleh penyelesaian soal yang tidak mampu mereka kerjakan dengan benar. Selain itu juga diketahui kesalahan dalam menarik kesimpulan ini karena memang langkah-langkah penyelesaian soal yang dilakukan mahasiswa salah ataupun tidak lengkap.

Berdasarkan hasil pengamatan dan kajian yang mendalam melalui penelitian ini diketahui bahwa kemampuan penalaran logis mahasiswa dalam menyelesaikan masalah merupakan hal yang perlu diperhatikan. Kemampuan bernalar logis untuk menyelesaikan masalah merupakan hal yang penting bagi mahasiswa. Sebagian besar mahasiswa telah mumpuni dalam bernalar secara logis ketika menyelesaikan permasalahan yang ada dalam tes kemampuan pada mata kuliah Pengantar Dasar Matematika. Namun demikian masih terdapat mahasiswa yang tingkat penalaran logisnya masih rendah. Hal ini disebabkan dalam penyusunan pemikiran atau argumentasi mahasiswa masih tergolong rendah, sehingga mahasiswa sulit dalam mengidentifikasi masalah selanjutnya tidak mampu menyelesaikan permasalahan dengan baik. Upaya yang perlu dilakukan adalah membantu mahasiswa dalam menyusun pemikiran yang benar dan dapat menyimpulkan dengan benar dan tidak hanya meningkatkan hasil belajar peserta didik, tetapi juga mampu mengembangkan kemampuan penalaran logisnya dalam menyelesaikan masalah. 


\section{KESIMPULAN}

Berdasarkan hasil penelitian yang telah dilakukan terhadap 30 orang mahasiswa pada tes I dan II, diketahui bahwa indikator kemampuan penalaran logis yang paling dominan adalah mengumpulkan fakta. Sedangkan indikator kemampuan penalaran logis yang masih rendah adalah menetapkan generalisasi dan kesimpulan. Selanjutnya sSaran dari penelitian ini adalah perlu adanyaperkuliahanyang menekankan untuk meningkatkan kemampuan penalaran logis terutama pada tahap membuat generalisasi dan menemukan cara penyelesaian berbeda untuk menguji kebenaran langkah-pemyelesaian yang telah dilakukan. Dengan kata lain mahasiswa dituntut untuk mampu untuk mengevaluasi kinerjanya sendiri dengan membuktikan kebearan jawabannya sendiri.

\section{DAFTAR PUSTAKA}

Arikunto, Suharsimi. 2010. Metode Penelitian Kualitatif. Bandung. PT Remaja : Rosda karya.

Bobbi Deporterdan Mike Hernacki. 2013. Quantum Learning Membiasakan Belajar Nyaman dan Menyenangkan. Bandung : Kaifa.

H. Bancong, Subaer. 2013. Profil Penalaran Logis Berdasarkan Gaya berpikir dalam Memecahkan Masalah Fisika Peserta Didik. Jurnal, tersedia di :http://journal.unnes.ac.id/nju/index.php/jpii.pdf (20 Februari 2015).

Hamzah, Ali. 2014. Evaluasi Pembelajaran Matematika. Jakarta : PT Raja Grafindo Persada.

Hidayat, Wahyu. 2013. Mengembangkan kemampuan komunikasi dan Berpikir Logisserta Disposisi Matematika Siswa SMA Melalui Pembelajaran Berbasis Masalah. Jurnal, tersedia di :http://wahyuhidayat.dosen.stkipsiliwangi.ac.id.pdf (20 Februari 2015).

Iskandar. 2009. Psikologi Pendidikan (Sebuah Orientasi Baru). Cipayung-Ciputat : Gaung Persada (GP) Press.

Jacob, C. 2007. Logika Informal : Pengembangan Pelanalaran Logis (Laporan Hasil Penelitian Hibah Kompetiti UPI 2007). Bandung :Universitas Pendidikan Indonesia. Jurnal, tersedia di: http://file.upi.edu./logikainformal/ARTIKEL_PENHIB.pdf (20 Februari 2015).

Kusumaningrum, Maya dan Saefudin, Abdul Aziz. 2012. Mengoptimalkan Kemampuan Berpikir Matematis Melalui Pemecahan Masalah matematika. Jurnal, tersedia di: http://eprints.uny.ac.id/8512/.pdf (20 Februari 2015).

M. Sukardjo dan Ukim Komarudin. 2010. Landasan Pendidikan Konsep dan Aplikasinya. Jakarta : PT. Raja Grafindo Persada.

Maksum. A'li. 2013. Profil Kemampuan Penalaran Matematis Siswa dalam Menyelesaikan Soal Bangun Ruang Sisi Lengkung. Jurnal, tersedia di :http//ejournal.stikpjb.ac.id/index.php/as/article/viewfile/197/133.pdf.(2 Agustus 2015).

Maran, R.R. 2007. Pengantar Logika. Jakarta : PT. Grasindo.

Moleong, Lexi J. 2010. Prosedur Penelitian Suatu Pendekatan Praktik. Jakarta : PT. Rineka Cipta. 
Ranjabar, Jacobus. 2014. Dasar-dasar Logika Sebuah Langkah Awal untuk Masuk ke Berbagai Disiplin Ilmu dan Pengetahuan. Bandung : Alfabeta.

Riduwan. 2014. Metode \& Teknik Menyusun Proposal Penelitian. Bandung : Alfabeta.

Satori, Djam'an Satori dan Komariah, Aan. 2011. Metodologi Penelitian Kualitatif. Bandung : Penerbit Alfabeta.

Setyawan, Dedy dan Rahman, Abdul. 2013. Eksplorasi Proses Kontruksi Pengetahuan Matematika Berdasarkan Gaya Berpikir. (On-line), tersedia di : http://ojs.unm.ac.id./index.php/sainsmat.com.pdf ( 20 Februari 2015).

Siswanto. 2005. Matematika Inovatif 1 Konsep dan Aplikasinya. Solo : PT Tiga Serangkai Pusaka Mandiri.

Soekadijo, R.G. 1983. Logika Dasar (Tradisional, Simbolik, dan Induktif). Jakarta : PT. Gramedia, Anggota IKAPI.

Sugiono. 2014. Metode Penelitian Pendidikan (Pendekatan Kuantitatif, Kualitatif, dan $R \& D)$. Bandung : Alfabeta.

Sukardi.2012. Metodologi Penelitian Pendidikan Kompetensi dan Praktiknya. Jakarta : Bumi Aksara

Sundayana, Rostina. 2013. Media PendidikanMatematika (untuk guru, calon guru, orang tua, dan para pecinta matematika). Bandung: Alfabeta.

Sutriningsi, Naning. 2015. Model Pembelajaran Assisted Individualization Berbasis Assessment For Learning pada Persamaan Garis Lurus ditinjau dari Karakteristik Cara Berpikir. Jurnal, tersediadi :http/e-DuMath/jurnalvol-1-no-1/43/51.pdf (2 Agustus 2015).

Usniati, Mia. 2011. Meningkatkan kemampuan Penalaran Matematika melalui Pendekatan Pemecahan Masalah. Jurnal, tersedia di: http://respository.uinjkt.ac.id/dspace/bits.pdf (20 Februari 2015).

Wahidmurni. 2010. Evaluasi Pembelajaran Kompetensi dan Praktik. Yogyakarta : Nuha Litera.

Yunusiyah, Rahmah El. 2014. Pengaruh Model Pembelejaran dan Kemampuan Berpikir Sekuensial terhadap Hasil Belajar Kewirausahaan di SMK Panca Budi-2 Medan. Jurnal, tersedia di: http://perpustakaan.unimed.ac.id/public/UNIMED.pdf ( 20 Februari 2015). 